\title{
A PLS Analysis On The Relationship Between Servant Leadership And Academicians OCB In MTUN Universities
}

\author{
Mehwish Rashid, Rosmaini Tasmin, Muhammad Imran Qureshi, Muhammad Shafiq
}

\begin{abstract}
There have been many research endeavours on the relationship between servant leadership and $O C B$. As servant leadership is widely used in education sector. Malaysian Technical University Network (MTUN) has its own importance in the Malaysian higher education. This study employed Structure Equation Modelling, and investigated the impact of five constructs of servant leadership on organizational citizenship behaviour. Partial least square is used to analyse the relationship. Results of this study show that servant leadership dimensions have significant positive relationship with academicians OCB. This study contributes empirically and theoretically to the body of knowledge in the fields of leadership and organizational behaviours.
\end{abstract}

Keywords

Servant leadership, Academicians OCB, MTUN

\section{INTRODUCTION}

Leadership is a vast and developed arena of knowledge, with a collection of styles and theories, for the followers and particular situations. There are many proposed definitions of leadership in the past, mostly determining leadership as a process, encompassing shared vision and goals in a group (Schreuder et al., 2011). Organ (1988), organization citizenship behavior (OCB) have a variety of forms including altruism, courtesy, sportsmanship, civic virtue and conscientiousness. According to Chompoukum, (2004) since organization citizenship behaviors are less likely to be formally rewarded than are required job behaviors. OCB are still primarily viewed as behaviors that are generally discretionary, and less likely to be formally or explicitly rewarded in an organization (Podsakoff et al., 2000). Academicians are the main contributor to the educational achievement of the university, and its departmental performance (Mahdinezhad \& Suandi, 2013). There are numerous studies to find the relationship of leadership styles and employees' performance but rarely research is conducted for academicians (Anyango, 2015; Pradeep \& Prabhu, 2011; Rasool, Arfeen, Mothi \& Aslam, 2015). This study is based on Social Exchange Theory (Blau, 1964), the followers who received genuine care from a servant leader

Revised Manuscript Received on April 19, 2019.

Mehwish Rashid, PhD scholar, Faculty of Technology Management and Business, Universti Tun Hussein Onn Malaysia, Johor Malaysia.

Rosmaini Tasmin, Associate Professor, Faculty of Technology Management and Business, Universiti Tun Hussein Onn Malaysia, Johor Malaysia.

Muhammad Imran Qureshi, Senior Lecturer, Faculty of technology Management and Technoprenurship, Universiti Teknikal Melaaca, Malaysia.

Muhammad Shafiq, Assistant Professor, Muhammad Ali Jinnah University, Karachi, Pakistan. would repay back with positive attitudes and it is a form of exchange in response to the leader's behavior. Consequently, servant leadership is described for empowering employees, maintaining good values leading towards OCB (Greenleaf, 1977; Russell, 2001).

Erturk (2006) reported academicians perform the task of teaching that is a complicated activity requiring professional reasoning. Macfarlane (2007) highlighted that most universities do not place academic citizenship as an important criteria for promotion based on an interview conducted in his study among academicians and it highlighted a voiced concern that what really mattered in such promotion decisions were contributions to research through publications and to obtain grant funding and very few universities provide an explicit 'weighting' for service or academic citizenship contributions

\section{LITERATURE REVIEW}

\section{A. Servant Leadership}

The outlines of the servant leadership theory were first set out by Greenleaf (1970), claiming that a new moral principle was developing concerning leadership. Servant leadership is defined as the leadership philosophy that focuses on developing employees to their full potential towards implementing tasks more efficiently, community leadership, self-motivation and future leadership ability (Grieves, 2010). Servant leadership offers a multidimensional leadership theory that encompasses all aspects of leadership, including ethical, relational, and outcome-based dimensions. Servant leadership has been found appropriate in the business, government and nonprofit sectors, and equally important and appropriate in the educational sector (Barbuto \& Wheeler, 2006). Drawn from Greenleaf's works Spears, presented ten main characteristics of servant leadership that is often referenced in servant leadership research. Listening, empathy, healing, awareness, persuasion, conceptualization, foresight, stewardship, commitment to the growth of others and building community are the ten identified characteristics of a servant leader (Kruit et al., 2011). Barbutto \& Wheeler (2006) five construct interpretation has been chosen in the theoretical framework as the independent variable of the present study. The five-construct of SL was Altruistic calling, Emotional healing, Wisdom, Persuasive mapping, and Organizational 
stewardship was chosen to measure servant leadership. This study was used 23 items of Servant Leadership Questionnaire of Barbutto \& Wheeler (2006).

\section{B. Altruistic calling}

This construct describes the leader's desire to make positive differences in the lives of others. Those leaders high in altruistic calling put the interest of others before themselves while working to meet the followers' needs (Barbuto Jr \& Wheeler, 2006). Altruistic behavior is often motivated by the empathy of a leader to benefit another person (Beck, 2014).

\section{Emotional healing}

The leader commits to fostering spiritual recovery from hardships by utilizing highly empathetic listening skills. The leader also creates an environment that is safe for followers to express their personal and professional concerns (Barbuto Jr \& Wheeler, 2006). Through empathy, an emotional response to the supposed plight of another, emotional healing takes the opportunity to see the circumstance through the other person's eyes, recognizing their individuality (Beck, 2014).

\section{Wisdom}

This variable is a combination of awareness of the surroundings and anticipatory consequences. Leaders, therefore, identify cues from the environment that combine knowledge and keen observation across functions and settings, therefore understanding their implications (Barbuto Jr \& Wheeler, 2006). The leader that demonstrates wisdom is very observant and anticipates outcomes (Paul, Smith \& Dochney, 2012).

\section{E. Persuasive mapping}

Barbuto Jr and Wheeler (2006) identified persuasive mapping as the extent leaders use sound reasoning when articulating opportunities. Through the encouragement of others, a visualization of the organizations future persuades followers to accomplish tasks. The ability to articulate, attract others, express passion regarding a vision are skills necessary for servant leaders to demonstrate to followers (Boone \& Makhani, 2012).

\section{F. Organizational stewardship}

Organizational stewardship is seeing the functionality of the organizations' ability to contribute to society through the influence of leadership. Greenleaf (1998) identified stewardship as holding something in trust. The organization and staff play a significant role in holding the institution in trust for the greater good of society.

\section{G. Organization citizenship behaviour (OCB)}

For any organization, the establishment of OCB is imperative. OCB is defined as employee behavior that exceeds the outlined job specifications that directly or indirectly facilitate the completion of organizational goals (Organ et al., 2005). OCB is defined as participating in activities or actions that are not formally a part of the job description, but that benefit the organization as a whole (Borman, 2004). OCB is often referred to as extra-role performance or contextual performance of employees
Bambale (2014). From the literature it is observed that leadership is the key agent in promoting OCB, different leadership components have a relationship with OCB (Poohongthong et al., 2014). Trust of the leader for their followers and making them empower will improve OCB among them (Runhaar et al., 2013). Results of previous studies reveal that more engaged lecturers are found more helpful towards colleagues. Similarly, more engaged lecturers show positive reaction towards the organization. In both cases, OCB plays its role (Runhaar et al., 2013). In fact, OCB is identified as an emerging field of study in education that can be very helpful in improving the overall efficiency of the universities (Kernodle \& Noble, 2013).

In the current study, the researcher investigated the OCB performance of academicians of MTUN universities, previous research in education reveals that individual benefits and organizational benefits are combine into one construct of OCB. In Malaysia, teachers or faculty staff are responsible to manage work regarding curriculum and cocurriculum; and they are also expected to give extra cares in guiding students. Hence, the role of OCB is also essential to fulfilling the National Educational Philosophy (NEP) of Malaysia. Awareness about OCB in university unit is beneficial for the educational activity, directly acting upon university performance (Popescu \& Deaconu, 2013). The current study adapted 8-item scale, the OCB Scale of DiPaola, (2005).

\section{THEORETICAL FRAMEWORK AND HYPOTHESES DEVELOPMENT}

In this part of the study, relationships, between all the variables of the study such as constructs of servant leadership, and OCB were discussed separately and built a hypothesis. As discussed before that the social exchange theory was used to support the framework of this study.

\section{RESEARCH FRAMEWORK OF THE STUDY}

\section{Servant Leadership}

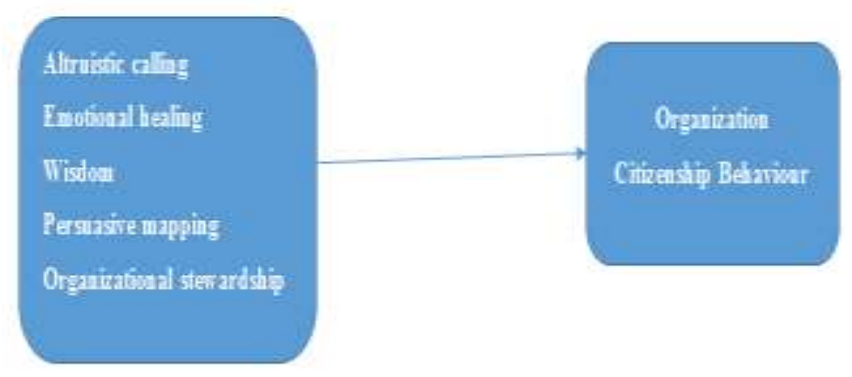

Figure 1: Research Framework of the study

\section{HYPOTHESIS OF THE STUDY}

This study was a direct relational study that investigated the relationship between constructs of Servant Leadership which are Altruistic calling, Emotional healing, Wisdom, Persuasive mapping, and Organizational stewardship with employee OCB. As stated by Dipaola et al. (2004), teaching 
is a complex activity that requires professional discretion; thus, OCB is a useful term to describe voluntary teachers "behavior's that go the extra mile" to help students and colleagues. OCB is essential because universities cannot anticipate through formally stated in-role job descriptions for achieving goals. Therefore, servant leadership differs from most other leadership approaches for its focus on personal integrity and forming of strong long-term relationships with employees. Researcher proposed that servant leaders contribute to increased OCBs by helping employees satisfy their need for autonomy and relatedness, because servant leaders build trustworthy dyadic relationships with followers and create a psychologically safe and fair climate where employees can truly be themselves and feel emotionally and cognitively connected to others, which naturally activates the drive to help colleagues and to act in the organization's best interest. According to the literature, $\mathrm{H} 1$ is the first hypothesis of the study, further subdivided in five hypothesis.

\section{H1. SL positively relate to employee $O C B$}

leader altruistic behavior is assumed as a feeling of empathy and concern for others and includes all discretionary behaviors which involve voluntarily helping others with work-related issues seeking to increase another's welfare, not one's own, and without expecting any reward. The first construct of servant leadership in this study was Altruistic calling and it shows a positive relationship between employee OCB behavior. Much like the Altruism dimension of servant leadership discussed earlier, helping behaviors are organizational citizenship behaviors related to the acts of encouragement, support, and assistance of coworkers in order to help them grow in the organization and overcome work-related problems. These behaviors are also referred to by scholars as "good colleague" behaviors (Lamertz, 2006). OCB in education centers primarily in the area of altruism. Altruistic behavior is the most commonly observed behavior in education because of the clientele of the profession. It is stated that "teachers routinely perform behaviors directed toward helping individuals, both students, and colleagues, as part of their professional identity" (Dipaola \& Mendes da Costa Neves, 2009). This aspect of leader supportiveness is helpful in employees' job satisfaction, which helps in increasing the level of OCB. The leader supportiveness also had a direct impact on generalized compliance aspect of OCB. So, researcher hypothesize that Altruistic calling construct of servant leadership questionnaire has a positive relationship with employee OCB behavior.

\section{H1a. Altruistic calling is positively related to $O C B$.}

The present study is aimed to examine the relationship between emotional healing and OCB among the academicians of MTUN universities. Liden et al. (2008) showed that helping subordinates enhanced ethics, and created value for the community, finding that emotional healing was significantly related to community citizenship behaviors, which included personal and organizational community service. Helping subordinates grow and succeed was supported as a way for servant leaders to influence followers to perform OCB (Ehrhart, 2004). Likewise, it was found a significant relationship between SL and OCB (Mirshekar \& Haddadi, 2017). Because leaders' Emotional healing had been linked to enhanced organizational climate (Newman \& Butler, 2014; Newman \& Smith, 2014; Sin \& Lyubomirsky, 2009), which was linked to employees' OCB (Gholami et al., 2015). Leaders who are perceived as able, and willing, to connect with followers on an emotional level (specifically in a healing context) build positive relationships with them and enhance their OCB as emotional healing has significant relationship with OCB. From previous literature (Liden, Panaccio, et al., 2014; Liden, Wayne, Liao, \& Meuser, 2014), the researcher found that there is a direct relationship between emotional healing and employee OCB. As a positive connection is found between emotional healing components of the leaders and the OCB's conducted by their followers (Yunus, Ishak, Mustapha \& Othman, 2010). Emotional healing of a leader may bridge the gap in the research to provide the context for examining leadership's effect on OCB. The emotional intelligence of an individual has been found to have a positive relationship with engaging in organizational citizenship behaviors directed at both individuals and organizations (Turnipseed \& Vandewaa, 2012). So by increasing the level of leader emotional healing, it can be strengthened the citizenship behavior of employees. So, according to the literature, the researcher hypothesize that

\section{$H 1 b$. Emotional healing is positively related to $O C B$.}

Wisdom, according to Barbuto Jr \& Wheeler (2006) is "the ability to see and learn from the environment, being able to see how it would affect each member and the organization". Leaders, high in wisdom can observe and expect the near and far future. Wisdom is a characteristic of leader who is aware of surrounding and can anticipate the consequences. The construct of wisdom has ancient foundations in the literature, but its measurement as an organizational leadership construct is relatively new. Recent research has led to the view and operationalization of wisdom as an attribute integrating the cognitive, effective, and reflective dimensions of human performance and behavior (Ardelt, 2003). Researchers and practitioners in leadership studies have suggested that wise leaders are essential to organizations (Kessler \& Bailey, 2007; Rooney \& McKenna, 2007). In the same manner, research has identified OCB as a representative factor that enhances cooperation and collaborative commitment in organizations (D Organ \& Podsakoff). Like wisdom, OCB is seen as critical to organizational effectiveness. Wise individuals experience more feelings of collaborative commitment to others (Kunzmann \& Baltes, 2003). A logical proposition is that there is a positive correlation between wisdom and OCB, specifically in leaders. This prediction is limited by the few empirical knowledge on wisdom in leadership studies, hence, scholars have called for more research on wisdom (Rooney, McKenna, \& Liesch, 2010). As, wisdom is the highest of human attributes (Kessler \& Bailey, 2007) and OCB relates to human performance outcomes (Organ et al., 2006), it is possible that a correlation exists between 
leader's wisdom and employee's OCB. When the consequences of the leader's wisdom are examined, it is expected to enhance OCB in the organization. Wise leaders develop high-quality relationships, therefore, it can be expected that these leaders will encourage high level of citizenship behavior. Similarly, employees who exhibit higher OCBs are more likely to be promoted, given highprofile assignments, and allowed greater autonomy in the workplace. Leader's wisdom plays an important role towards OCB. Leader's wisdom creates an environment through which an individual can think, feel, and behave in certain ways and as OCB is discretionary, there is prediction of a strong relationship between leader's wisdom and faculty OCB in MTUN universities

\section{H1c. Wisdom is positively related to $O C B$.}

The fourth construct of Servant Leadership study in this study was 'persuasive mapping'. Persuasive mapping is the ability of leader to envision mental outlines that mapped issues allowing greater opportunities for the entire organization. Mapping provides an inspirational, futuristic approach to rational influence (Yukl \& Michel, 2006). Effective persuasive mapping encourages others to visualize the organization's future in such a way that is persuasive and offers compelling reasons to get followers to engage. Persuasive mapping implies and ability to forecast the future and prepare an organization to sustain a course to achieve its goals (Barbuto \& Wheeler, 2006). Such skills lend themselves to task-oriented behaviors whereas the successful completion of one task provides a step forward to the next task and onward to a final goal. Persuasive mapping reflects the leader inspiring and encouraging behavior that helps to foster the OCB behavior in organizations (Bass, 2000). If the academic leaders of MTUN universities practicing the attribute of leader persuasive mapping, it may defiantly help to promote its follower OCB role in universities. So, according to the literature, researcher hypothesize that;

\section{Hld. Persuasive mapping is positively related to $O C B$.}

Barbuto \& Wheeler (2006) defined organizational stewardship as extending leadership beyond the organization by taking responsibility for the well-being of the community. Servant leaders are considered as stewards of the organization who are devoted to empowering the potential of their followers. The benefits of leader stewardship can provide to a community building at work, it is possible that the organization could significantly encourage the establishment of the former for the employees to perform OCB to their organization and coworkers. As mentioned earlier, sense of community is about working in a place where employees can feel that there is a strong connection between the coworkers (Ashmos \& Duchon, 2000). Recent research of Ramli, Desa \& Ramayah (2014), revealed that servant leadership dimensions of accountability and stewardship are positively predicting civic virtue dimension of OCB. Civic virtue refers to the behavior on the part of an individual that indicates that one responsibly participates in the life of the organization. Stewardship is related to social responsibility, loyalty, and teamwork that represent a feeling of identification with and

sense of obligation to a common good. Accordingly, the previous research of Kuppelwieser (2011), both the need for and the use of leader stewardship behavior are more highly marked in service organizations and in universities. The current research adds to the existing leadership literature by applying the stewardship concept in MTUN universities demonstrates positive relationship between leader stewardship and its follower OCB.

\section{H1e. Organizational stewardship is positively related to $O C B$.}

\section{RESEARCH METHODOLOGY}

\section{Unit of analysis}

The unit of analysis for this quantitative data collection was individual's academicians of MTUN universities. This study was basically intended to measure the OCB of faculty members (Lecturers, Senior Lecturers, Associate Professors, and Professors) of MTUN universities (UTHM, UniMAP, UMP, and UTeM). The respondents of this study were the faculty staff of the technical universities of Malaysia. The list of respondents was taken from staff directory of each university's website. So, the academicians of these four technical universities are considered as key respondent of this study.

\section{Analysis}

Reliability analysis of all the constructs of the study was performed. Al the constructs have the cronbach alpha above 0.8 which is satisfactory (Nunnally, 1978).

\begin{tabular}{lll}
\multicolumn{3}{c}{ Table2: Reliability } \\
\hline Construct & No Role & Cronbach \\
& of & Alpha \\
& Items &
\end{tabular}

Altruistic Calling $4 \quad$ Independent $\quad 0.820$

$\begin{array}{llll}\text { Emotional Healing } & 4 & \text { Independent } & 0.833 \\ \text { Wisdom } & 5 & \text { Independent } & 0.857 \\ \text { Persuasive } & 5 & \text { Independent } & 0.838 \\ \text { Mapping } & 5 & \text { Independent } & 0.829\end{array}$

Organizational

Stewardship

$\begin{array}{llll}\text { Organizational } & 8 & \text { Dependent } & 0.814 \\ \text { Citizenship } & & & \\ \text { Behaviour } & & \end{array}$


Table $3 \quad$ Multicollinearity

TOLERANCE VALUE

Model

$\begin{array}{lll} & \begin{array}{c}\text { Toler } \\ \text { ance }\end{array} & \text { VIF } \\ \text { Altruistic Calling } & .341 & 2.456 \\ \text { Emotional Healing } & .363 & 3.264 \\ \text { Wisdom } & .348 & 3.564 \\ \text { Persuasive Mapping } & .372 & 3.657 \\ \begin{array}{l}\text { Organizational } \\ \text { Stewardship }\end{array} & .378 & 3.124 \\ \end{array}$

\section{Dependent Variable: Organizational Citizenship Behaviour}

As the values of tolerance are more than 0.10 , this indicates that the multicollinearity assumption was not violated. The VIF values, also less than five which supports the fact that the assumption of multicollinearity is met.

\section{Measurement Model}

The below figure depicts the measurement model of the figure, where at the left side are the exogenous means independent variables of the study, which are basically the five constructs of the servant leadership. While the organizational citizenship behaviour is at the right side as the dependent variable of the study.

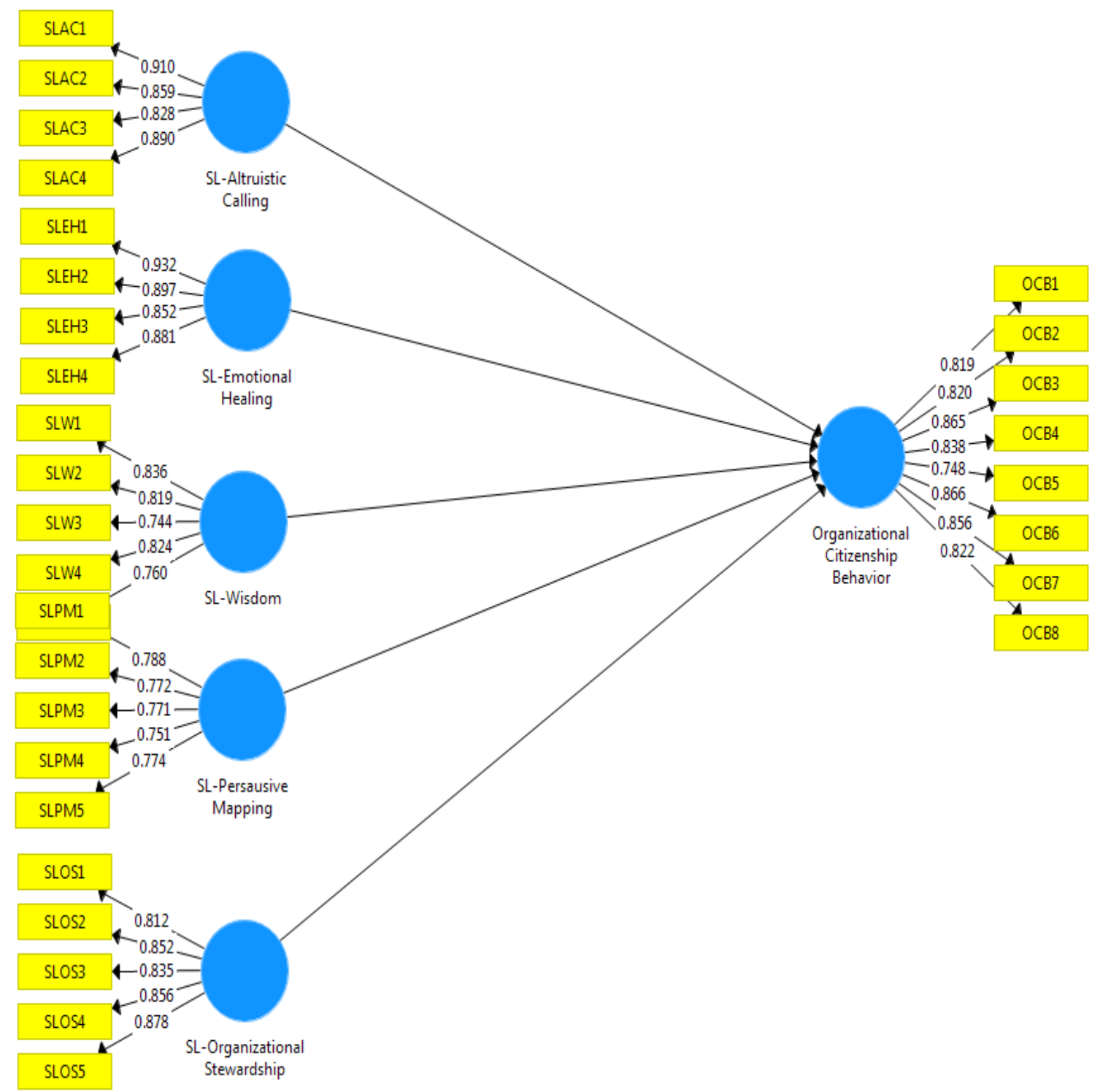


International Conference on Recents Advancements in Engineering and Technology (ICRAET-18) |15th and 16th March 2019|Siddhartha Institute of Technology \& Sciences, Telangana, India.

The construct validity and discriminant validity of the study was performed next, which shows that all the constructs have Average variance extract (AVE) above 0.5 value while the items' loadings are above 0.7 . while he

values of croanbach alpha and the composite validities are above 0.8 for all constructs.

Discriminant Validity

Table 4.1: Fornell-Larcker criteria

(*Square root of average variance extraction)

\begin{tabular}{|c|c|c|c|c|c|c|c|}
\hline & IEC & OCB & SLAC & SLEH & SLOS & SLPM & SLW \\
\hline IEC & 0.795 & & & & & & \\
\hline OCB & -0.167 & 0.733 & & & & & \\
\hline SLAC & -0.072 & 0.478 & 0.868 & & & & \\
\hline SLEH & -0.074 & 0.416 & 0.638 & 0.945 & & & \\
\hline SLOS & -0.223 & 0.810 & 0.579 & 0.454 & 0.915 & & \\
\hline SLPM & -0.148 & 0.656 & 0.571 & 0.578 & 0.725 & 0.874 & \\
\hline SLW & -0.187 & 0.584 & 0.657 & 0.467 & 0.726 & 0.710 & 0.922 \\
\hline
\end{tabular}

The diagonal values show that correlation among the

Construct Validity constructs itself is the highest.

Table Items outer loadings and AVE for constructs

\begin{tabular}{|c|c|c|c|c|c|}
\hline Constructs & Items & $\begin{array}{l}\text { Factor } \\
\text { Loadings }\end{array}$ & AVE & $\begin{array}{l}\text { Composite } \\
\text { Reliability }\end{array}$ & $\begin{array}{l}\text { Cronbach } \\
\text { alpha }\end{array}$ \\
\hline \multirow[t]{4}{*}{ SL-Altruistic Calling } & SLAC1 & 0.809 & \multirow[t]{4}{*}{0.661} & \multirow[t]{4}{*}{0.847} & \multirow[t]{4}{*}{0.857} \\
\hline & $\overline{\text { SLAC2 }}$ & 0.760 & & & \\
\hline & SLAC3 & 0.728 & & & \\
\hline & SLAC4 & 0.780 & & & \\
\hline \multirow[t]{4}{*}{ SL-Emotional Healing } & SLEH1 & $\overline{0.843}$ & \multirow[t]{4}{*}{0.574} & \multirow[t]{4}{*}{0.835} & \multirow[t]{4}{*}{$\overline{0.846}$} \\
\hline & SLEH2 & 0.876 & & & \\
\hline & SLEH3 & 0.852 & & & \\
\hline & SLEH4 & 0.882 & & & \\
\hline \multirow[t]{5}{*}{ SL-Wisdom } & SLW1 & 0.839 & \multirow[t]{5}{*}{0.736} & \multirow[t]{5}{*}{0.856} & \multirow[t]{5}{*}{0.897} \\
\hline & SLW2 & $\overline{0.819}$ & & & \\
\hline & SLW3 & 0.747 & & & \\
\hline & SLW4 & 0.823 & & & \\
\hline & SLW5 & 0.755 & & & \\
\hline \multirow{3}{*}{$\begin{array}{c}\text { SL-Persuasive } \\
\text { Mapping }\end{array}$} & SLPM1 & 0.787 & \multirow[t]{3}{*}{0.695} & \multirow[t]{3}{*}{0.880} & \multirow[t]{3}{*}{0.830} \\
\hline & SLPM2 & 0.773 & & & \\
\hline & SLPM3 & 0.768 & & & \\
\hline
\end{tabular}


Table: Items outer loadings and AVE for constructs (continued)

\begin{tabular}{|c|c|c|c|c|c|}
\hline & SLPM4 & 0.753 & & & \\
\hline & SLPM5 & 0.777 & & & \\
\hline \multirow{5}{*}{$\begin{array}{l}\text { SL-Organizational } \\
\text { Stewardship }\end{array}$} & SLOS1 & 0.814 & \multirow[t]{5}{*}{0.617} & \multirow[t]{5}{*}{0.910} & \multirow[t]{5}{*}{0.891} \\
\hline & SLOS2 & 0.853 & & & \\
\hline & SLOS3 & 0.835 & & & \\
\hline & SLOS4 & 0.856 & & & \\
\hline & SLOS5 & 0.876 & & & \\
\hline \multirow{8}{*}{$\begin{array}{c}\text { Organizational } \\
\text { Citizenship Behavior }\end{array}$} & OCB1 & 0.819 & \multirow[t]{6}{*}{0.589} & \multirow[t]{6}{*}{0.898} & \multirow[t]{6}{*}{0.875} \\
\hline & OCB2 & 0.820 & & & \\
\hline & OCB3 & 0.865 & & & \\
\hline & OCB4 & 0.837 & & & \\
\hline & OCB5 & 0.749 & & & \\
\hline & OCB6 & 0.866 & & & \\
\hline & OCB7 & 0.857 & & & \\
\hline & OCB8 & 0.822 & & & \\
\hline
\end{tabular}

Coefficient of determination (R2) of endogenous constructs

\begin{tabular}{|c|c|}
\hline Constructs & R Square \\
\hline $\begin{array}{c}\text { Organizational Citizenship } \\
\text { Behavior }\end{array}$ & 0.675 \\
\hline
\end{tabular}

\section{F. Direct Effect}

Direct effect of servant leadership on OCB was measured by running the bootstrapping for the model. Bootstrapping technique gives the results for each hypothesis. The cut off values are 1.64 for the $\mathrm{t}$ because the hypothesis are directional while 0.05 confidence level for $\mathrm{p}$. The results show that four of the five hypothesis have positive and significant relationship between servant leadership and academician's OCB. This shows that emotional healing does not have a significant relationship with the academician's OCB.

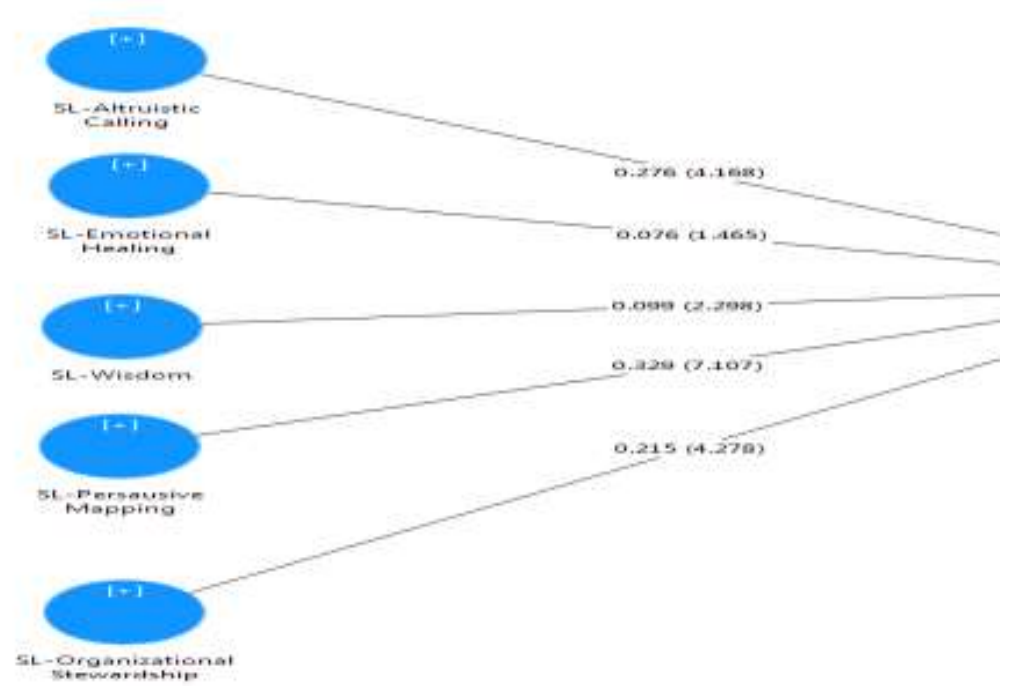


International Conference on Recents Advancements in Engineering and Technology (ICRAET-18) |15th and 16th March 2019|Siddhartha Institute of Technology \& Sciences, Telangana, India.

Table Direct hypothesis results:

\begin{tabular}{|l|l|l|l|l|}
\hline $\begin{array}{l}\text { Hypoth } \\
\text { esis }\end{array}$ & Paths & $\begin{array}{l}\text { Path } \\
\text { Coefficie } \\
\text { nt }\end{array}$ & S.E & t-v \\
\hline H1a & Altruistic calling -> OCB & 0.227 & 0.064 & 2.5 \\
\hline H1b & $\begin{array}{l}\text { Emotional Healing } \\
\text { OCB }\end{array}$ & 0.054 & 0.051 \\
\hline H1c & $\begin{array}{l}\text { Wisdom -> OCB } \\
\text { H1d }\end{array}$ & $\begin{array}{l}\text { Persuasive Mapping }-> \\
\text { OCB }\end{array}$ & 0.316 & 0.045 \\
\hline H1e & $\begin{array}{l}\text { Organizational } \\
\text { Stewardship -> OCB }\end{array}$ & 0.197 & 0.050 & 2.043 \\
\hline
\end{tabular}

$\mathrm{S} . \mathrm{E}=$ Standard Error, $\mathrm{T}$ Value $=\mathrm{t}$ statistic value, $\mathrm{P}$ value $=$ Probability value

\section{CONCLUSION}

This research helps us to understand that four of the five servant leadership constructs contribute to OCB positively and significantly in Malaysian Technicla universities network (MTUN). Researcher propose a model of servant leadership which supports OCB.

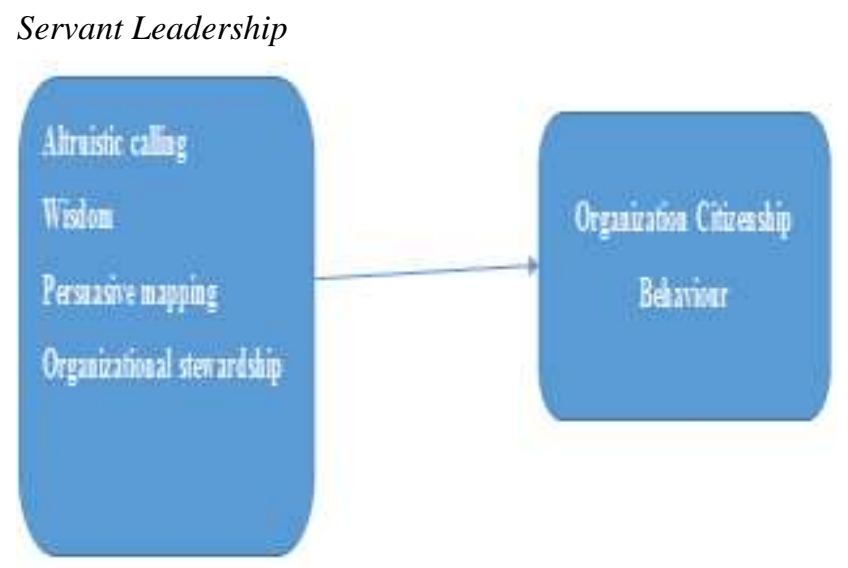

Figure : Developed Model of Servant leadership for
OCB

\section{ACKNOWLEDGEMENT}

"This paper is sponsored by the Research Management Center (RMC) of Universiti Tun Hussein Onn Malaysia (UTHM), Johor Malaysia”

\section{REFERENCES}

1. Schreuder, J. A., Roelen, C. A., Van Zweeden, N. F., Jongsma, D., Van der Klink, J. J., \& Groothoff, J. W. (2011). Leadership effectiveness and recorded sickness absence among nursing staff: a cross-sectional pilot study. Journal of Nursing Management, 19(5), 585-595.

2. Organ, D. (2006). Treating employees fairly and OCB: sorting the effect of job satisfaction, organizational commitment and procedural justice: Plenum Publishing Corporation: USA.

Bootstrapped

Interval

\begin{tabular}{|l|l|l|}
\hline $\begin{array}{l}2.5 \% \\
\text { LL }\end{array}$ & $\begin{array}{l}97.5 \% \\
\text { UL }\end{array}$ & Results \\
\hline 0.124 & 0.330 & Supported \\
\hline-0.032 & 0.138 & $\begin{array}{l}\text { not } \\
\text { supported }\end{array}$ \\
\hline 0.010 & 0.152 & Supported \\
\hline 0.243 & 0.393 & Supported \\
\hline 0.113 & 0.280 & Supported \\
\hline
\end{tabular}

3. Organ, D., \& Podsakoff, P. MacKenzie.(2006). Organizational citizenship behavior: Its nature, antecedents, and consequences.

4. Organ, D. W. (1988). A restatement of the satisfactionperformance hypothesis. Journal of management, 14(4), 547-557.

5. Organ, D. W., Podsakoff, P. M., \& MacKenzie, S. B. (2005). Organizational citizenship behavior: Its nature, antecedents, and consequences: Sage Publications.

6. Yukl, G., \& Michel, J. W. (2006). Proactive influence tactics and leader member exchange. Power and influence in organizations, 87-103.

7. Rooney, D. (2013). Empirical wisdom research: A community approach Wise management in organisational complexity (pp. 34-52): Springer.

8. Kessler, E. H., \& Bailey, J. R. (2007). Handbook of organizational and managerial wisdom: Sage Publications.

9. Barbuto, J. E., \& Wheeler, D. W. (2002). Becoming a servant leader: Do you have what it takes? : Cooperative Extension, Institute of Agriculture and Natural Resources, University of Nebraska-Lincoln.

10. Barbuto Jr, J. E., Fritz, S. M., \& Marx, D. (2002). A field examination of two measures of work motivation as predictors of leaders' influence tactics. The Journal of social psychology, 142(5), 601-616.

11. Bass, B. M., \& Riggio, R. E. (2010). The transformational model of leadership. Leading organizations: Perspectives for a new era, 2, 76-86.

12. Boone, H. N., \& Boone, D. A. (2012). Analyzing likert data. Journal of extension, 50(2), 1-5.

13. Bryman, A. (2012). Social research methods: OUP Oxford.

14. Bryman, A., \& Bell, E. (2015). Business research methods: Oxford University Press, USA.

15. Caldwell, C., \& Dixon, R. D. (2010). Love, forgiveness, and trust: Critical values of the modern leader. Journal of Business Ethics, 93(1), 91-101.

16. Dipaola, M., Tarter, C., \& Hoy, W. (2004). Measuring organisational citizenship of schools: The organizational citizenship behavior scale. Educational Administration Quarterly, 42(3), 385-423.

17. DiPaola, M., Tarter, C., \& Hoy, W. (2005). Measuring organizational citizenship in schools: The OCB scale. Educational leadership and reform, 4, 319-341. 
18. Henseler, J., Dijkstra, T. K., Sarstedt, M., Ringle, C. M., Diamantopoulos, A., Straub, D. W., . . Calantone, R. J. (2014). Common beliefs and reality about PLS: Comments on Rönkkö and Evermann (2013). Organizational Research Methods, 17(2), 182-209.

19. Jiang, J. Y., Zhang, X., \& Tjosvold, D. (2013). Emotion regulation as a boundary condition of the relationship between team conflict and performance: A multi-level examination. Journal of Organizational Behavior, 34(5), 714-734.

20. Johnson, B., \& Christensen, L. (2008). Educational research: Quantitative, qualitative, and mixed approaches: Sage.

21. Kalshoven, K., Den Hartog, D. N., \& De Hoogh, A. H. (2011). Ethical leader behavior and big five factors of personality. Journal of Business Ethics, 100(2), 349-366.

22. Kamarolzaman, N. Z. H., \& Sepikun, M. H. (2011). The Effectiveness of Teaching among Electrical Lecturer from Not Education Background. Politeknik Port Dickson, Negeri Sembilan.

23. Lee, N., Zvonkovic, A. M., \& Crawford, D. W. (2014). The impact of work-family conflict and facilitation on women's perceptions of role balance. Journal of Family Issues, 35(9), 1252-1274.

24. Leff, S. S., Baker, C. N., Waasdorp, T. E., Vaughn, N. A., Bevans, K. B., Thomas, N. A., . . Monopoli, W. J. (2014). Social cognitions, distress, and leadership selfefficacy: Associations with aggression for high-risk minority youth. Development and psychopathology, 26(3), 759-772.

25. Miao, Q., Newman, A., Schwarz, G., \& Xu, L. (2014). Servant leadership, trust, and the organizational commitment of public sector employees in China. Public Administration, 92(3), 727-743. 